\title{
Crosschecking teachers' perspectives on learning in a one-to-one environment with their actual classroom behavior - a longitudinal study
}

\author{
Yehuda Peled ${ }^{1}(1) \cdot$ Ina Blau $^{2}(1) \cdot$ Ronen Grinberg $^{3}(1)$
}

Received: 14 June 2021 / Accepted: 8 November 2021 /Published online: 5 January 2022

(c) The Author(s), under exclusive licence to Springer Science+Business Media, LLC, part of Springer Nature 2021

\begin{abstract}
One-to-one laptop initiatives have become prevalent in schools aiming to enhance active learning and assist students in developing twenty-first-century skills. This paper reports on a qualitative investigation of teachers in a junior high school in Northern Israel, who were gradually implementing one-to-one computing. The research reported in this paper is based on longitudinal data collected over a fiveyear period and included all of the teachers who participated in the project. We triangulated teachers' perspectives and actual behavior by employing classroom observations, followed up with semi-structured interviews. This study aims to map teachers' perspectives on changes in teaching in one-to-one computing settings, and the pedagogical strategies that they use in one-to-one classrooms. To explore the depth of change in teaching, teachers' perspectives were mapped based on the SAMR framework, while the TEUCT-TEUIT approach was employed to categorize pedagogical strategies. The findings pointed to several benefits of using a laptop for teaching, as well as classroom management problems and technological problems while teaching. Analysis of the interviews revealed four categories which appeared in the original TEUCT/ TEUCT scales, alongside three additional categories which did not appear in the original scales, and emerged bottom-up from our data. Furthermore, findings indicated that some of the categories originally included in TEUCT, should rather be included in the TEUIT scale. The findings point to a change in teaching strategies, from a more teacher-centered teaching approach to a more student-centered learning approach.
\end{abstract}

Keywords One-to-one computing · Technology in education · Technology integration in $\mathrm{K}-12 \cdot$ Middle school teachers

Yehuda Peled

yehudap@wgalil.ac.il

Extended author information available on the last page of the article 


\section{Introduction}

Technology is a powerful educational tool, but technology per se does not produce profound pedagogical changes (Peled et al., 2015). The effective use of Information Communication Technology (ICT) in teaching and learning is a complex and multifaceted process that includes various teacher level and school level conditions (Aydin et al., 2016; Vanderlinde, \& van Braak, 2011). Research classifies several factors that facilitate (or act as barriers to) the effective use of ICT in schools by teachers as either arising from the external environment or teachers' characteristics - including the beliefs, values, and perceptions that are likely to influence them.

Personal factors: These are all factors related to the individual teacher, such as knowledge and skills, beliefs, availability in terms of time, and previous engagement in the use of technology in teaching (Agyei \& Voogt, 2012).

Institutional factors: The primary institutional factor influencing the continuous use of technology following participation in professional development programs is the value and belief system of the school, provision of motivation for teachers in the form of rewards, incentives and financial support by the school administration (Håkansson Lindqvist, 2019; Dong et al., 2019).

Technological factors: Ease of use, which refers to the convenience, adequacy, reliability, and user-friendliness of the technology (Kafyulilo et al., 2016) and ongoing technical support (Selwyn et al., 2017).

\subsection{One-to-one technology initiatives}

One-to-one initiatives in education refer to the practice according to which schools provide each student with a computing device, such as a laptop or tablet, in order for the students to access the Internet, digital course materials, and digital textbooks (Vu et al., 2019). The term one-to-one indicates the ratio of one computer, laptop, or tablet for each student and teacher.

Research claims that one-to-one initiatives have allowed teachers to improve their teaching and instructional practices, as well as their proficiency in utilizing technology (Lee et al., 2015), and thus expands the educational repertoire (Peled et al., 2015). The three most common goals that schools have developed for migrating to one-to-one computing are: (1) to enable teachers and software to design, customize and deliver more personalized content to learners; (2) to advance learners' technology skills; and (3) to enable the students to do more complex and creative work (Vu et al., 2019).

\subsection{Context of the study}

This study examined teachers' perceptions regarding various aspects of teaching in a one-to-one computing environment. Among the one-to-one computing environment studies, some included single data collection, whether prior to, during, or after 
the implementation. Some used a very small sample, such as Sockman (2007), who explored seven teachers' perceptions of their progress toward becoming facilitators of students' learning in one-to-one computing environments. Similarly, small samples were used by Bermel (2016), who collected data from semi-structured interviews with four administrators and eight teachers from a suburban midwestern American secondary school, and by Jacob (2020), who used a sample of eight volunteer teachers from both primary and secondary schools.

Various research has investigated the perceptions of specific subject matter teachers, such as science teachers' perceptions of the effects of one-to-one computing devices on student engagement (Bocchino III, 2017), language arts teachers' perceptions of changes in their instruction with the introduction of a one-to- one learning environment (Martin, 2015), English/language arts teachers' and principals' perceptions of the value of one-to-one student laptops (Wolfe, 2018), and a comparison of perceptions of technology conducted between teachers in schools with and without one-to-one computing (Frankson, 2018).

Other studies used quantitative methods based on self-report questionnaires (Hershkovitz \& Bransi, 2019; AlMannai, 2017; Schott, 2012; Solomon, 2018; Greene, 2019) or triangulated quantitative data with qualitative, mainly self-report, data. For example, Wright (2019) and McDonald (2015) collected data using a survey and a follow-up interview. Redmond (2018) collected data from several sources, such as questionnaires, interviews, and analysis of documents.

Several studies employed a case study method in order to understand the implications of teaching in one-to-one classrooms. Some examined the perceptions that preservice teachers held regarding their readiness to step into one-to-one classrooms upon completion of their teacher candidacy program (Jeffery, 2019). Others explored in-service high school teachers' perceptions of facilitating conditions prior to the implementation of a one-to-one learning environment (Lawrence, 2018). Knops (2017) used a case study methodology to analyze how professional development is perceived by teachers as it relates to their integration of one-to-one technology into instruction, and what type of professional development teachers prefer in order to meaningfully implement one-to-one technology in their instruction. For the purpose of this research, we used two frameworks which are presented in the following sections. To explore the depth of change in teaching, we mapped teachers' perspectives based on the SAMR (Hilton, 2016; Puentedura, 2006) framework. Furthermore, to categorize pedagogical strategies, we employed the TEUCT-TEUIT approach (Badia et al., 2015).

\subsection{The SAMR model}

The SAMR model provides teachers with a framework meant to boost the combination of emerging technologies in their classrooms (Hilton, 2016). This wellestablished model features a four-level approach to selecting, using, and evaluating the added value of technology in K-12 education. This model was chosen for this study, since, in line with Puentedura (2006), it's intended to be a tool through which one may describe and categorize K-12 teachers' pedagogical usage of classroom 
technology. In step with the SAMR model, the utilization of technology is categorized as four hierarchical levels: substitution, augmentation, modification, and redefinition. Substitution is that the use of technology despite the likelihood of the learning task being completed without technology. Augmentation enhances a learning task which will be accomplished without technology. Modification supports the alteration of a previous task in a way that is difficult without the employment of technology. These tasks are classified under two different categories, enhancement, and transformation, as suggested by Puentedura (2012). Substitution and augmentation tasks are classified under "enhancement", touching on the primary stage of the model, within which technology is employed to substitute and/or enhance existing tools within the learning task. In contrast, modification and redefinition tasks are classified under "transformation", the second stage of the model, involving new ways and opportunities for learning that don't seem to be easily accomplished without technology (Kirkland, 2014).

\subsection{The TEUCT- TEUIT scale}

The use of computers in the classroom involves the use of ICT during lessons, as an integral part of the teacher's teaching and the students' learning. In order to have a higher understanding of how ICT is used by teachers and students as a teaching and learning tool in the classroom, Badia et al.'s (2015) scale was used, which identifies two factors, each divided into four categories that classify the educational uses of ICT for teaching. These factors were named (1) "Teachers' Educational Use of Content Technologies (TEUCT)" which refers to research and educational practice related to what teachers do with ICT in relation to the content they teach, including using ICT to do the following: support the oral presentation of content, present contents through a multimedia or hypermedia system, support conversations with students, and show examples of products (learning outcomes) that students are required to develop; and (2) "Teachers' Educational Use of Interaction Technologies (TEUIT)" - This factor includes the teaching tasks that characterize the educational interactions between teachers and students, which include the following: extending classroom activities to the virtual classroom (asynchronous and written communication, and the provision of educational and evaluative aids to facilitate content learning during and after school hours), communicating with students, monitoring progress in the learning process, and providing guidance and guidelines to facilitate learning.

\subsection{Teachers' perceptions of ICT implementation in one-to-one classrooms}

Studies on teachers' perceptions of technology and one-to-one laptop use in classrooms indicate multiple perspectives on use, motivation, effectiveness, and student achievement. Some teachers understand the benefits of ICT integration, but are not ready to adopt it due to various challenges (Maiima et al., 2013), such as insufficient technological support (Selwyn et al., 2017), and absence of clear school policies related to ICT integration (Salam et al., 2018). 
The standard model of technology diffusion argues that changing teachers' perceptions and epistemological beliefs regarding the value of an innovation is conducive to successful implementation (Yuen et al., 2003). For instance, teachers' positive belief in the benefits of laptops in teaching and learning was found to be a major factor facilitating the successful use of laptops in the classroom (Munyengabe et al., 2017). Others argue that changing teachers' conceptions does not necessarily effect change in their practices and student learning ( $\mathrm{Li}, 2010)$, and that all professional development (PD) training and mentoring of one-to-one programs should deal explicitly with how technology changes the perception of the teacher's role and their professional identity (Doron \& Spektor-Levy, 2019).

Technical support is crucial for successful ICT integration (Abdelrahman et al., 2019; Atman Uslu \& Usluel, 2019; Lawrence, 2018). Lei (2010) report that teachers' perceptions of the availability of technological support decreased over time. This change was not limited to the first year, but occurred during the following years as well. Teachers reported that with increased technology use, more technological support was needed, so it took longer for the technology support team to address each teachers' technological needs. When technical support and PD were not sufficiently offered, teachers' negative perceptions of laptop programs persisted (Lei et al., 2007).

To integrate ICT effectively, teachers need to adopt different teaching strategies. For instance, learners may take a more active role in their learning, as the teacher alone will no longer direct the control and flow of information (Sahoo, 2019). Acceptance of technological innovations was also found to be significantly and positively related with innovative technology-enhanced pedagogy (Willis et al., 2019). The creation of digital content which has a capacity to open up new strategies for learning and teaching is an important skill, which has been found to be strongly related to the purposeful implementation of ICT in the classroom (Willis et al., 2019). In a study conducted in 10 secondary schools, Sahoo (2019) found that using ICT in the classroom influenced the teachers' approach to teaching. Namely, when teachers used ICT with their students, they are engaged in different styles of delivery, with less planning and more spontaneity. Teachers said they put more emphasis on how students learned, as well as what they learned. Teachers labelled themselves not as teachers, but as facilitators. Nonetheless, the impact of integrating ICT in the classroom on teaching and learning strategies varies (Gerez, 2019), and in some cases teaching methods have not changed with the integration of ICT into the classroom (Buabeng-Andoh, 2012).

And last, but not least, the school's policy and the principal's attitude toward oneto-one implementation have been found to be a major factor influencing the success of ICT integration (Peled et al., 2011; Huang \& Teo, 2019; Moreira et al., 2019). Furthermore, the organization's innovation climate has been found to be significantly and positively related with innovative technology-enhanced teaching (Willis et al., 2019).

In an evaluation study of a large scale, one-to-one project which provided handheld devices to more than 15,000 students in 12 middle schools, Strudler and Schrader (2016) found teachers' perception of hurdles to device use to be "off-task behavior" which was the biggest concern, followed by "not all students 
had them". Additional hurdles were lack of time for planning, connectivity, technical problems, the lack of fit between the use of devices and the curriculum, and the need for more PD. For example, Fiorillo (2015) reported teachers' perception that students were off task and disengaged more often than before the implementation of a Chromebook integration initiative. In a two year follow up study conducted by Sprenger (2010), findings indicated increased perceptions of the value of authentic learning, increased perceptions of the value of formal collaborative learning, increased use and perceptions of the value of online learning activities, significant changes indicating increased use, and perceptions of the value of learning centers.

\section{Objective of the study}

The uniqueness of the research reported in this paper is in its depth and that in number of ways: The longitudinal data collection - over a five-year period; the sample type - including all of the teachers who participated in the one-to-one initiative explored in this study; the data collection that triangulated teachers' perspectives with their actual behavior and included classroom observations followed up by interviews. Thus, this research reveals what actually occurs in a one-to-one classroom, alongside teachers' experiences of these occurrences. One of the main focuses of the study was to examine the level of ICT use by teachers, and the way in which they use it. As the objective of the one-to-one initiative is to enhance teaching and learning, it is important to ensure that teachers use the technology to change students' engagement in these processes, and adapt their teaching to realize the added value of the one-to-one environment.

One of the research objectives was to examine additional categories that may be useful in classifying the possible educational uses of ICT for teaching and learning in classrooms. Although the TEUCT-TEUIT scales were based on three theoretical frameworks (technology use, the instructional role of the technology, and the correspondence of the technology and educational rational), all three related to various dimensions of technology in teaching, thus ignoring issues related to class management and learning management. Therefore, an additional purpose of the current study was to validate (or reject) Badia et al.'s (2015) TEUCT/ TEUIT scales.

This study aims to map (1) teachers' perspectives on changes in teaching in one-to-one learning environments, as well as (2) pedagogical strategies which teachers use in one-to-one classrooms.

Considering the above, the current study explores two research questions:

Research question \#1: How do teachers perceive the changes in teaching related to one-to-one integration at school?

Research question \#2: What are the pedagogical strategies that teachers actually employ in one-to-one classrooms? 
Table 1 Observations: Teachers' demographics

\begin{tabular}{llllll}
\hline Gender & Male & & & Female \\
\cline { 6 - 6 } \cline { 5 - 6 } $\begin{array}{l}\text { Seniority in } \\
\text { teaching }\end{array}$ & $\begin{array}{l}\text { Less than } \\
\text { 10 years }\end{array}$ & $\begin{array}{l}\text { More than } \\
\text { 10 years }\end{array}$ & & $\begin{array}{l}\text { Less than } \\
10 \text { years }\end{array}$ & $\begin{array}{l}\text { More } \\
\text { than } \\
10 \text { years }\end{array}$ \\
\hline $\mathrm{N}$ & 5 & 2 & 2 & 11 \\
$\%$ & 25 & 10 & 10 & 55 \\
\hline
\end{tabular}

Table 2 Interviews

\begin{tabular}{llllll}
\hline & \multicolumn{3}{l}{ Male } & & Female \\
\cline { 2 - 3 } \cline { 5 - 6 } & $\begin{array}{l}\text { Less than } \\
\text { 10 years }\end{array}$ & $\begin{array}{l}\text { More than } \\
\text { 10 years }\end{array}$ & & $\begin{array}{l}\text { Less than } \\
10 \text { years }\end{array}$ & $\begin{array}{l}\text { More } \\
\text { than } \\
10 \text { years }\end{array}$ \\
\hline $\mathrm{N}$ & 8 & 3 & 11 & 18 \\
$\%$ & 20 & 7.5 & & 27.5 & 45 \\
\hline
\end{tabular}

\section{Methodology}

\subsection{Participants}

Twenty teachers (13 female and 7 male) were observed while teaching in one-toone classrooms (see Table 1), and following the observation, the teachers were interviewed.

Additional interviews were conducted with 20 teachers who were not observed. In total, forty teachers (29 female and 11 male) were interviewed (see Table 2).

\subsection{Instruments and procedure}

This research was conducted using a qualitative approach, aiming to reveal the pedagogical approach of teachers from their attitudes and classroom behavior. The study was approved by the institutional Ethics Committee and by the Ministry of Education. The semi-structured interviews lasted approximately $40 \mathrm{~min}$, and were conducted immediately after the class observation. In total, forty interviews were conducted. The interview contained three parts: (1) Background questions. For example: What is your previous background in computer use for teaching? What were your expectations from the transition from traditional teaching to teaching in a one-to-one environment? (2) Pedagogical attitudes and behaviors. For example: What do you think are the benefits of a computer use for teaching? Is your teaching progressing as planned? In which aspects, if any, are your pedagogical strategies and the progress of the class similar to last year? In which aspects, if any, is your teaching and/or the progress of the class different? 
Please explain why. (3) Students' learning. For example: Please describe how you manage the one-to-one class. What is the evidence of students' learning in a one-to-one classroom, and how do you define success in this environment? What are the changes, if any, in students' learning strategies in a one-to-one classroom?

All the teachers received an invitation form to participate in the study, which included an interview and viewing of the lesson. The letter explained the objectives of the research and its connection to the implementation of the computers in the $1 \times 1$ model in the school. Teachers were asked if they agreed to be interviewed for the study and if they agreed to allow observation of the class they were teaching. All teachers who agreed to participate in the study were interviewed at the school in a semi-structured interview that lasted an average of one hour. A short while (before or after the interview) there was an uninterrupted observation in the classroom. The teachers were prepared for the observation and knew that its purpose was to observe how the students' personal computers were being used.

The observer sat in the last row of the class. He observed the teacher and his/ her interaction with the students. He also looked at the students in order to identify their reactions to the teacher's activities. If there was teamwork, he moved between the teams. Prior to analyzing the interview transcripts, we conducted an extensive literature review on one-to-one laptop initiatives, to help inform our analysis. The categorization was based on two theoretical models relating to the use of laptops for teaching and learning by teachers and students. The various uses of technology in the classroom were classified into the categories proposed by Badia et al. (2015) and the SAMR model (Puentedura, 2012). All of the interview transcripts were read twice. In the first reading round, 132 categories were identified. In the second reading, categories that were identified only once or twice, or that were provided by only one teacher, were omitted. Similar categories were consolidated, and categories were then re-categorized. Following the second round of reading, the remaining 21 categories were grouped into four primary categories: Teachers' Educational Use of Interaction Technologies (TEUIT); Educational uses of technology by teachers to support teaching-learning of content' (TEUCT); Disadvantages of one-to-one computing; Advantages of one-to-one computing. The transcripts of the observations were encoded according to the same categories, along with a list of general data pertaining to the observations, such as the number of students in the class, the number of laptops, and the main uses of the laptops by the teacher and students.

\section{Findings}

\subsection{Changes in teaching related to integration of one-to-one computing}

The first research question referred to pedagogic, technical, and managerial (classroom management) changes. As Table 3 shows, all of the added values mentioned by the teachers were directly related to teaching, pedagogy, and classroom management. The main drawbacks were related to classroom management - namely, discipline and technical problems. Additionally, Table 4 details pedagogical strategies 


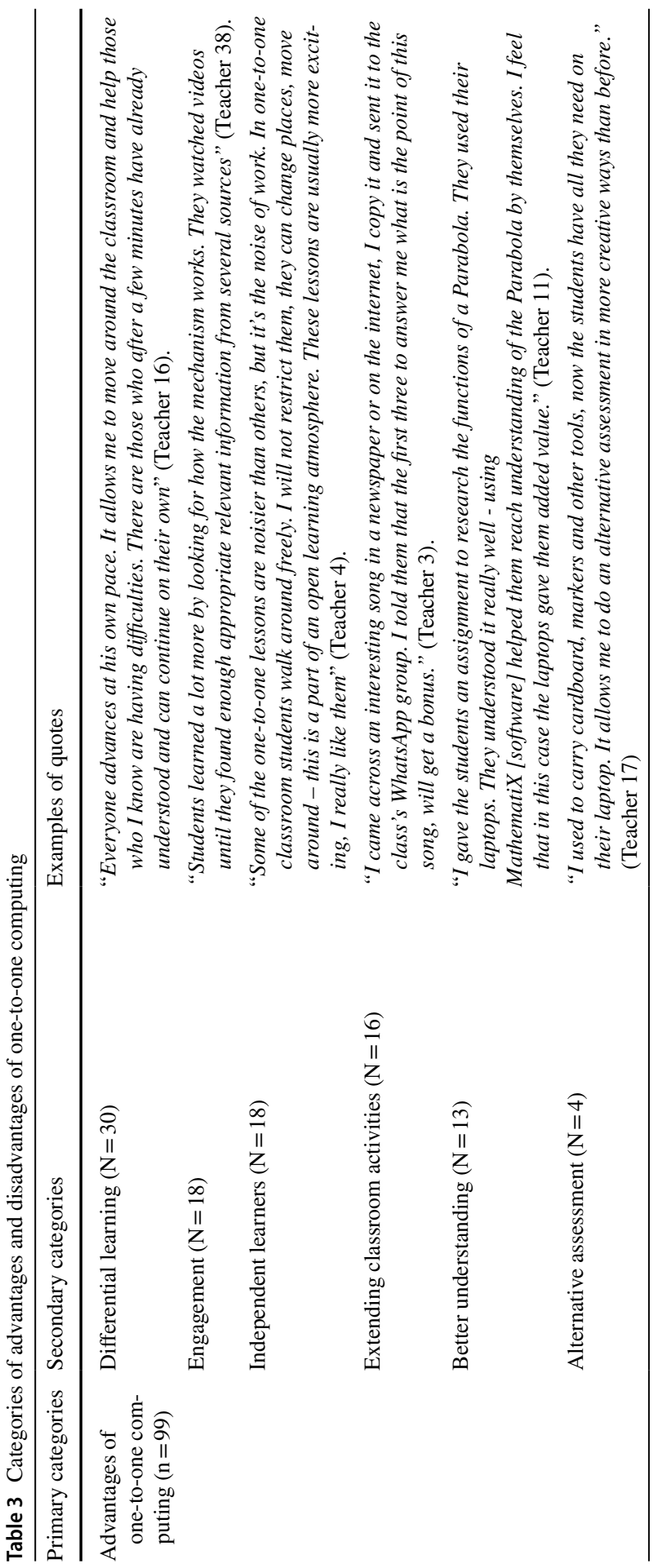




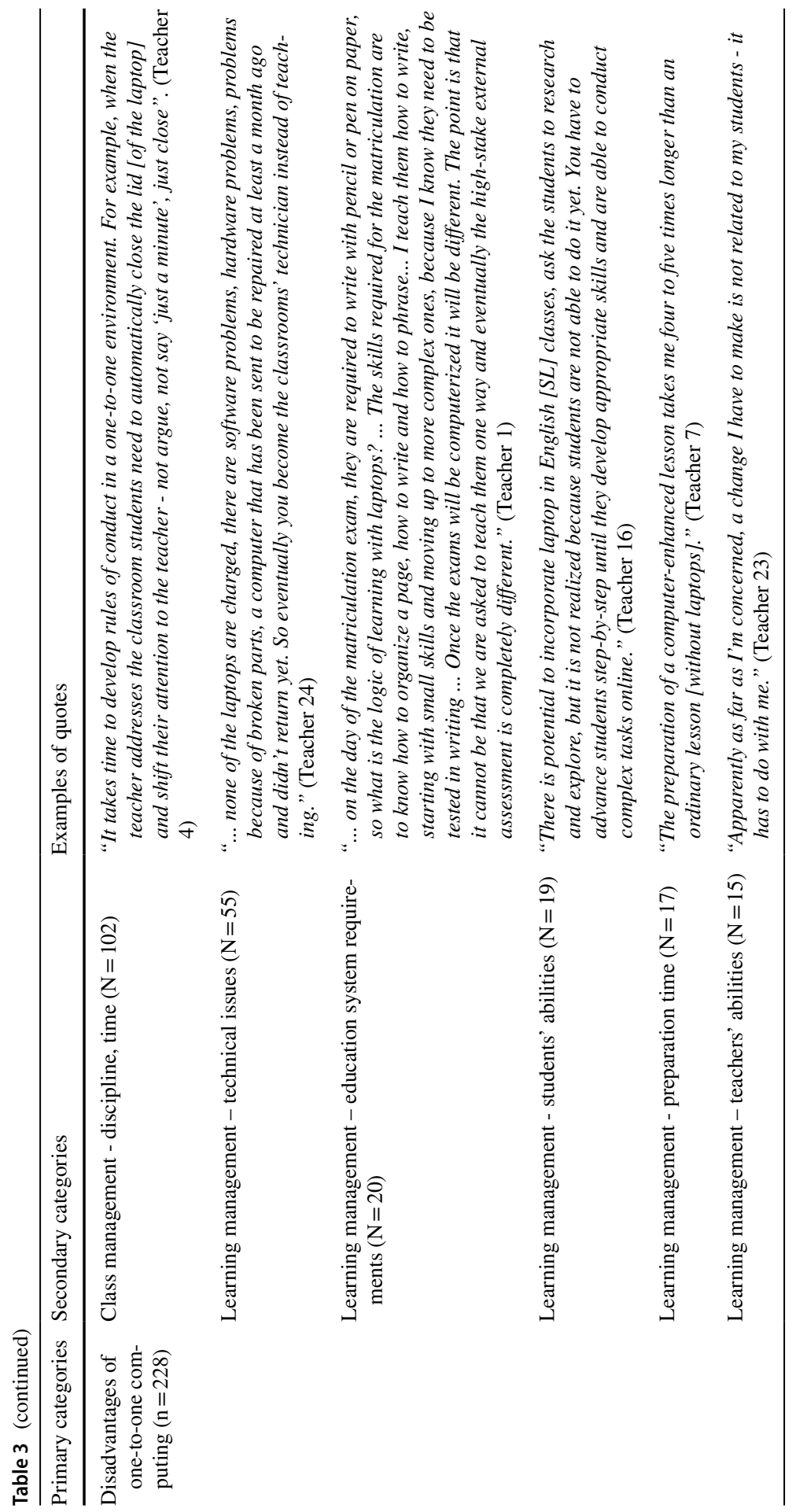




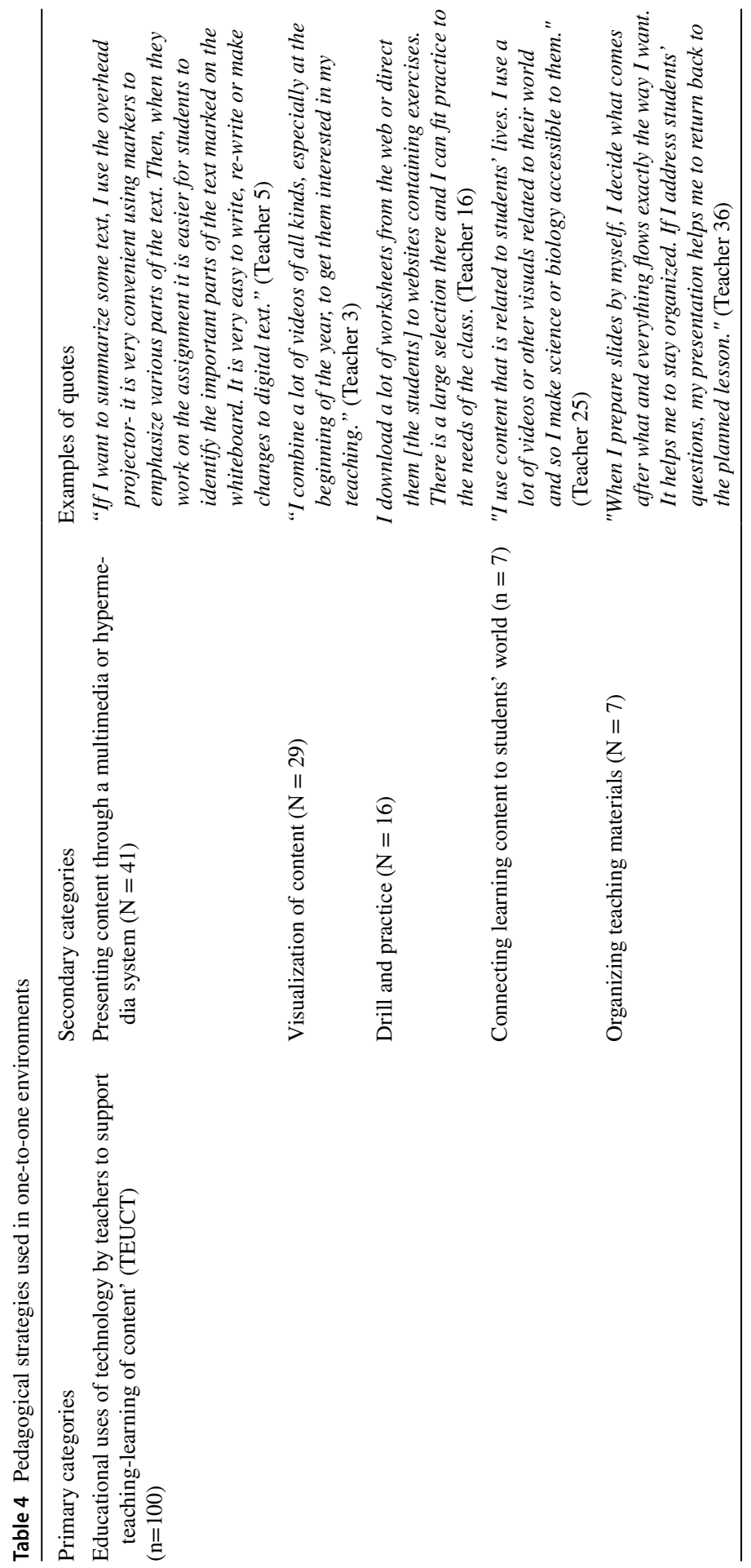




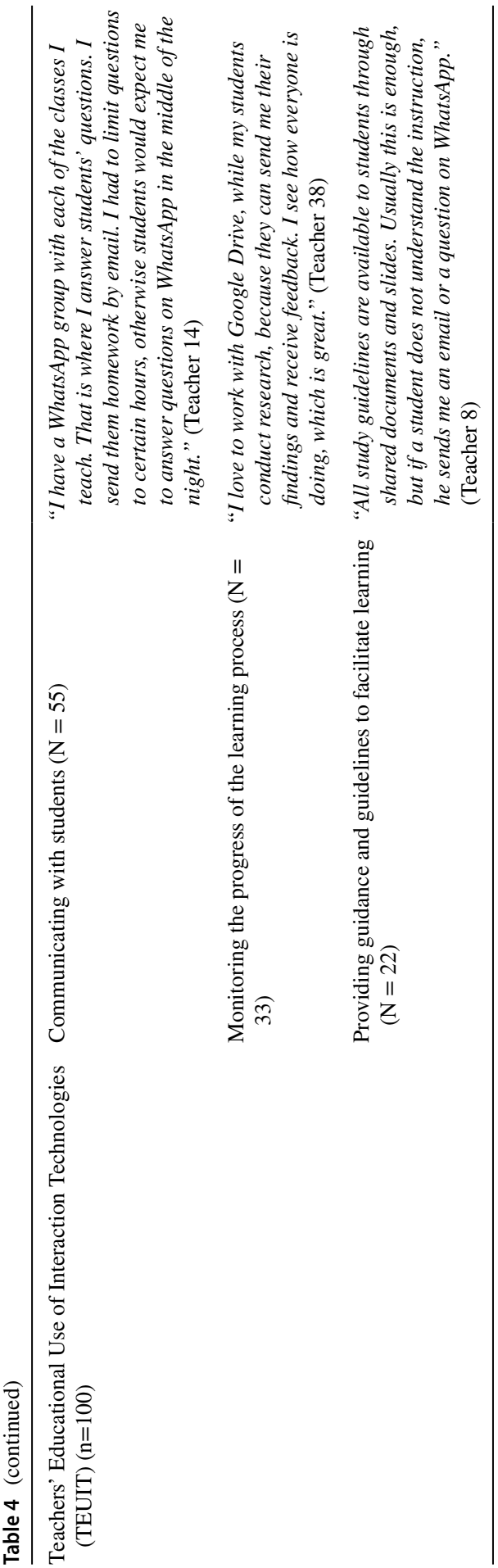


used in one-to-one environments. While some teachers described shaping their own lessons and were engaged in creation and change, other teachers reported using materials from content providers or other teachers. Still other teachers described themselves as somewhere in between the two extremes, and adapted existing content for their class.

More than half of the teachers claimed that the one-to-one computing has no effect on the "traditional pedagogy", and indeed most of the statements describe the use of "substitution" - the lowest level in the SAMR model. Furthermore, most teachers reported using materials from content providers, whereas less than half reported designing their own teaching materials. From the teachers' comments, seven advantages of one-to-one computing can be defined in relation to the learning process: (1) the possibility of differential learning; (2) increased involvement in learning processes; (3) cultivation of self-regulated learners; (4) extending classroom activities beyond school's space and time; (5) better understanding of the material being studied; (6) the advantage of using a laptop for the teacher; and (7) the cultivation of creativity. Furthermore, two advantages that teachers noted in relation to the learning organization were: (1) expanding learning beyond the lesson time and the classroom walls, and (2) reducing lesson preparation time.

Teachers described one of the advantages of the one-to-one computing to be that it allows them to move around the classroom and help those who they know are having difficulties, noting those students who have understood after a few minutes and can continue on their own. The following two advantages arose from the teachers' remarks: (1) the involvement of learners in the learning process and (2) the cultivation of independent learning habits. In most subjects, explanations were provided as a whole-class teaching, while laptops were used in individual learning or teamwork. In the case of inquiry-based learning and alternative assessment (assessment for learning), students' laptops played a central role.

Discipline was the biggest problem that teachers expressed in the one-to-one model, especially describing difficulty in controlling the students' use of their laptop during class. Although it seems sometimes that students are busy doing other things, such as surfing the web, chatting with classmates, some teachers felt they do learn. According to those teachers, students want to do what is required of them, and they want to submit the assignments, since they worked on it because they wanted to and not because the teacher told them to. There was positive evidence of independent learning, apparent by the fact that most of the students were absorbed in the tasks given. If there was noise in the classroom, it was a byproduct of interest in learning, which did not interfere with the class conduct, nor disturb the teacher.

The last of the advantages teachers mentioned in relation to the learning process in the classroom was the cultivation of creativity. The teachers who mentioned creativity noted the importance of assessment, such as creating videos instead of writing reading reports which enabled rich self-expression and diverse students' outcomes.

Two advantages that emerged from the teachers' statements were related to the learning organization: (1) The expansion of learning beyond the boundaries of time and space of the classroom, enabled continued learning and dialogue between the teacher and the students and between the students outside of the boundaries of the classroom; and (2) sharing the learning materials with the students. 
More than half of the teachers claimed that the one-to-one model had no effect on "traditional pedagogy", and indeed most of the statements described the use of "substitution" - the lowest level in the SAMR model. Whereas some teachers designed their lessons and were engaged in design of their own learning materials, the majority of teachers used materials from content providers or other teachers, and still other teachers adapted existing content for their class.

The total number of statements that reflected the disadvantages of using laptops in teaching and learning was twice as many in comparison with the statements that describe the advantages. The most obvious disadvantage that appeared in teachers' testimonies was classroom management - namely, discipline, and as a result, time management. One of the common disciplinary issues was students coming to school without their laptops or with an un-charged battery. Another issue was that students were often tempted to use their laptop for other things than learning during class, including games, surfing the web, and listening to music.

Technical problems were the second most common drawback of the one-to-one model. Some of the technical problems mentioned were depleted batteries, hardware and software issues, broken parts, a laptop that was sent to be repaired for a month, during which time the student had to work without it. The teachers felt that they had to deal with trivial issues, acting as the classrooms' technician, leaving them little time to teach.

Some statements described the discrepancy between learning with laptops and the requirements of the matriculation exam. In certain subjects, such as history, social studies, and Bible studies, in which the school can determine approximately $30 \%$ of the matriculation exam in the form of alternative assessment, the teachers used computer-based research. However, in most subjects, the matriculation exams are written exams. According to the teachers, preparing the students for that type of exam, which is based on a large amount of learning material that must be covered in a short period of time, is not possible if it has to be done with laptops. In contrast to the teachers who mentioned the advantage of using a computer in terms of reducing lesson preparation time, other teachers noted the opposite - the preparation of a computer-based lesson took them more time than preparing a lesson without computers. Difficulties stemming from teachers' personal competencies and preferences, such as their attitude towards computer-based teaching and learning, were expressed. Some teachers felt that students were learning to use new software or applications very quickly, whereas for them, learning to use new software or a new application could take several weeks, putting them at a disadvantage compared to their students.

\subsection{Pedagogical strategies that teachers use in one-to-one classrooms}

Here we will examine the 'Teachers' Educational Use of Content Technologies' (TEUCT) and 'Teachers' Educational Use of Interaction Technologies' (TEUIT) scales developed by Badia et al. (2015) and their expansion / adaptation. Three categories which did not appear in the original TEUCT/TEUIT scales emerged 
bottom-up from the interviews. On the other hand, we identified four new categories which will be described below.

\subsection{Educational uses of technology by teachers to support content teaching (TEUCT)}

The first new category in the TEUCT scale which emerged from the interviews may be generalized as 'using ICT for visualization of content', in addition to the existing category, 'presenting contents through multimedia or hypermedia systems. While the existing category relates to the means of presentation - multimedia and hypermedia, the new category emphasizes the type of content - text, picture, video, sound, etc. A justification for considering the 'use ICT for visualization of content' as a separate component is that sometimes the use of visual presentation supports the learning process through reading or watching pictures or video clips, and not necessarily through oral instruction.

The second new category in the TEUCT scale may be generalized as 'providing drills or exercises' (see Table 4). In this case, it is important to distinguish between different types of practice. While often, this may refer to replacing a 'pen and a paper technology', it is sometimes a more complex practice that takes advantage of the interactivity of the computer. Although the most prominent of the four categories in the TEUCT scale is 'supporting conversations with students', none of the teachers mentioned this in their reports.

The third new category that was found was 'connecting the learning content to the students' world' (see Table 4). The existing category, 'supporting dialogue with students', is too broad, and interviews showed no evidence of support for the use of computers in educational discourse, apart from the visual presentation of content (in the wake of which a discourse develops) and the possibility of connecting the subject being taught to the students' world. None of the teachers related to the category 'showing examples of products that students are required to develop'. The interviews did not indicate that the teachers use laptops to present best examples before performing a task (a pedagogical best practice which should be emphasized as important, but apparently did not occur in the current study). The fourth new category that was found was 'organizing the teaching materials', whereby teachers organized the teaching material for themselves, but indicated that this organization directly contributed to communication with the students.

\subsection{Teachers' educational use of interaction technologies (TEUIT)}

The first three categories in the TEUIT scale are consistent with the categories that emerged from the interviews (see Table 4). A category that exists in the original scale, and was not identified in the interviews, is "extending the classroom to the virtual classroom'. The absence of this category from the interviews is related to the basic uses in the SAMR model (Substitution and Augmentation) which were found to be the most common uses of ICT by the teachers in the study. 
Almost all teachers communicated with their students using WhatsApp primarily. Some teachers had WhatsApp groups according to the different groups they taught, and they utilized this to send homework, send messages, and extend learning beyond the classroom's space and time limits. Each educator (usually a homeroom teacher) had a WhatsApp group with his/her students. Teachers who did not want to open groups with all of their students were assisted by a homeroom teacher to send messages to their students. Communication also took place via e-mail, especially to transfer work pages, presentations, learning tasks, and online tests.

One of the advantages teachers noted was the ability to track the learning process and give feedback in real time. Namely, the students' use of files that are shared with the teacher enabled them to keep track of their work and give immediate feedback during the learning process.A component that does not appear in Badia et al. (2015), and is seemingly unrelated to the teachers' interaction with learners, is the organization of online learning materials by the teacher. Although the organization of learning materials was done by the teacher for himself/herself, it helped students who missed a class or did not take notes, since they could go online and download the learning materials. Neither the teachers' interviews nor the observations indicated evidence of the component of expanding the classroom into a virtual classroom.

\section{Discussion}

\subsection{Teachers' perceptions of the changes in teaching following implementation of the one-to-one model at school}

The findings indicated several benefits of using a laptop for teaching, including differential learning, engagement, independent learning, extending classroom activity beyond school's space and time, and cultivating better understanding and creativity. Nevertheless, there were also several challenges of using a laptop for teaching. These challenges included discipline issues, technical issues, the educational system requirements, students' abilities, time needed for preparation of digital learning materials, and teachers' abilities.

The most striking advantage of teaching using laptops in the one-to-one model, as expressed by the number of statements that can be attributed to it, is the ability to teach differentially, that is, the ability to enable each student to learn at his or her own pace. Thus, access to the internet can provide a pathway to active and engaged learning, in which participants construct knowledge through social interaction and exploration (Kamel Boulos \& Wheeler, 2007), allowing users to work at their own pace and supporting students' metacognition (Michalsky, Zion, \& Mevarech, 2007).

Several teachers noted that in classes without laptops, they felt responsible for their students' learning and understanding, whereas in the classes in which the students' study with their personal laptops, the students assumed responsibility for their own learning. This demonstrates a positive characteristic of the change in teaching and learning practices derived from the one-to-one computing initiative. These findings are supported by Bergström and Mårell-Olsson (2018), who report students having greater control in one-to-one computing settings. 
Research indicates that one-to-one laptop programs enhance independent learning (Fiorillo, 2015) and shift the relationship between student and teacher, creating a more independent learning environment for students and extending the relationship beyond the typical school day (Higgins, 2015).

Promoting creativity was mentioned by the teachers' numerous times as an advantage in relation to the learning process in the classroom. This suggests that devices should be used to foster creativity and higher-level thinking skills, as supported by Hershkovitz and Karni (2018) and Doron and Spektor-Levy (2019). Teachers also took advantage of the one-to-one model to extend the learning outside of the classroom by organizing the learning materials in shared files with the students and supplying students with the class presentations. This is supported by previous reports, which describe the ability to share and organize resources and documents with students as an important advantage of one-toone programs. For example, students can wirelessly project content from their devices to instantly share their work and discuss it with their classmates (Perry, 2018; Varier et al., 2017; Kim et al., 2019). These advantages are categorized under level 2 of the SAMR model - augmentation of the teaching materials.

More than half of the teachers claimed that the one-to-one model had no effect on traditional pedagogy, and indeed most of the statements described the use of "substitution" - the lowest level in the SAMR model. In addition, the majority of teachers used materials from content providers, and less than half of them designed their own teaching materials. Puentedura (2012) suggests that it can take up to three years after exposure to technology before instruction moves from basic implementation to practice that is considered more transformational. The teachers in this study received most of their materials from external sources and these were used to substitute the previous content, rather than augmenting the teaching materials, with only a fraction of the teachers modifying or redefining their teaching materials. As this data was collected in the fifth year of the project, this seems to imply that the expected change in teaching did not seep in deep enough. This finding can be explained by the concept of teachers as designers (Laurillard, 2013; Mor et al., 2015), whereby teachers who design their own learning activities integrate them with teaching to the best of their ability, and generally incorporate more teaching tools into their teaching (Cviko et al., 2011).

In this study, the biggest problem that teachers expressed in relation to learning via personal laptops was classroom management problems, and especially the ability to control the students' use of the laptop during class. As with other areas of teaching, planning lessons that account for various learning styles, and require students to do most of the cognitive work during class, should reduce disengaged behaviors (Fiorillo, 2015). Difficulties related to technological issues were raised by $90 \%$ of the teachers, stating that technological problems are an issue. In a one-to-one computing school, technology issues should be reduced to a minimum, so that teachers are able to channel their energy into classroom and learning management. 


\subsection{Pedagogical strategies that teachers use in one-to-one classrooms}

The scales developed by Badia et al. (2015) were used to categorize various uses of technology for teaching. Namely, the analysis was based on the 'teachers' educational use of content technologies' (TEUCT) category, which refers to research and educational practice related to what the teacher does in relation to the learning content, and the 'teachers' educational use of interaction technologies' (TEUIT) category, which accounts for how the teacher uses technology to establish educational interactions with students. The interviews addressed four of the categories which appeared in the original scales: presenting content through a multimedia or hypermedia system, communicating with students, providing guidance and guidelines to facilitate learning, and monitoring progress in the learning process. Another three categories did not appear in the original scales and emerged from bottom-up data analysis: drill and practice, organizing learning materials, and connecting the learning content to the students' world. Four of the original categories were not identified in the interviews: extending the classroom to the virtual classroom, showing examples of outcomes or artifacts that students are required to develop, supporting conversations with students, and supporting the oral presentation of content. Furthermore, we argue that some of the categories originally defined in the TEUCT scale should rather be included in the TEUIT scale. The categories in the TEUCT and TEUIT scales are not discussed in detail in the original article, thus we extracted their meaning from the little available information. Table 5 describes the new categorizations, which reflect our findings and our understanding of both scales.

According to the original scale, 'communicating with students' relates to any kind of communication between the teacher and students, whether using asynchronous communication (e-mail) or synchronous communication (Messenger, Skype, or similar). In contrast, 'supporting conversations with students' relates to the content edited by the teacher himself/herself or other online resources with the purpose of supporting students' teamwork. Thus, this category can be defined as the educational use of technologies to support content-related interactions. Since, according to brief explanations in the original article, the main objective of the supporting

Table 5 New classification

TEUCT

Presenting content through a multimedia or hypermedia system

*Visualization of content

* Drilling and practicing

*Connecting learning content to the students' world

Supporting oral presentation of content

*Organizing teaching materials

Showing examples of outcomes or artifacts that students are required to develop

\section{TEUIT}

Communicating with students

Providing guidance and guidelines to facilitate learning

**Supporting conversation with students

Extending the classroom to the virtual classroom Monitoring the progress of the learning process

* Represents a new category; ** represents a category which was moved from one scale to another 
conversation with students' category is to forward references of online sources to the students using various online platforms or software in order to support students' teamwork, we argue that it is more suitable to be included in the 'Teachers' educational use of interaction technologies' scale, rather than the 'Teachers' educational use of content technologies' scale.

* Represents a new category; ** represents a category which was moved from one scale to another.

Two of the new categories, showing examples of learning outcomes that students are required to develop, and supporting conversations with students are advanced teaching strategies, whereas drilling and practicing is a traditional strategy. As a teaching strategy is a series of systematic behaviors conducted by the teacher in the teaching process, it includes a method aimed at solving a certain practical teaching problem. Therefore, teaching strategies play an important role in the effectiveness of teaching. The findings point to a change in teaching strategies, from a more teachercentered teaching approach to a more student-centered learning approach, which is related to the changing the role of teacher "from sage on the stage to guide on the side" (Blau et al., 2016; Wang \& Zhang, 2019).

\section{Conclusions and recommendations}

The intended contribution of this research was to map teachers' perspectives on changes in teaching in one-to-one learning environments, as well as pedagogical strategies which teachers use in one-to-one classrooms.

For a one-to-one computing program to have a positive effect, it takes a really very long time and involves profound fundamental changes in teaching practices, perceptions, beliefs, and attitudes (Doron \& Spektor-Levy, 2019). To realize such a fundamental effect, the school must do rather more than purchase mobile devices and provide students and teachers with access to them 24/7. Technology implementation could be a complex process that needs a comprehensive approach that transforms school culture, changes the very nature of teaching and learning, and expands the boundaries of the school and classroom (Shapley et al., 2010).

This study crosschecked participant perspectives in interviews with actual classroom behavior in lessons' observations. Although a non-participant observation is a well-established research method in formal education settings, the limitation of this method is that we can't completely exclude that students behave slightly different in presence of the observer, especially at the beginning.

Current circumstances (the Covid-19 pandemic) present a novel window of opportunity for schools to implement one-to-one programs. Despite these driving forces, school leaders must bear in mind the impact (or lack thereof) that such programs have on teaching, moreover because the multiple factors that influence the success of one-to-one programs. Leadership, organizational support, and professional development are positively correlated with classroom immersion (Williams $\&$ Larwin, 2016). Thus, based on the present study findings and previous studies, schools should think about the subsequent before implementing a one-to-one program: 
1. Do not re-invent the wheel - visit schools that already have a one-to-one program. Learn from them what works and what does not.

2. Develop a multi-year plan for preparation, implementation, and full deployment of the one-to-one program in light of the school's goals (Williams \& Larwin, 2016).

3. Plan a whole school year for professional development in order to shift teachers' attitudes and proficiency and develop teachers' abilities to integrate their knowledge of technology with knowledge of content and pedagogy before advancing to the students' phase (Scott \& Mouza, 2007).

4. Set clear expectations regarding the frequency and type of use of technology in the classroom.

One-to-one computing programs have the potential to improve students' achievement and have, in fact, successfully attained this goal in many schools.

Availability of data and material Not applicable.

Authors' contributions Authors' contributions are as stated in the authors list.

\section{Declarations}

Conflicts of interest/competing interests (declaration of conflicting interests The authors declared no potential conflicts of interest with respect to the research, authorship, and/or publication of this article.

Code availability Not applicable.

Ethics approval IRB was approved.

Consent to participate All participants signed a consent form.

Consent for publication Not applicable.

\section{References}

Abdelrahman, M. A., Abdelraheem, A. Y., Al-Shedani, Z. A., \& Al Aghbari, M. S. (2019). An investigation of faculty members' beliefs and barriers to successful ICT integration into teaching at Sultan Qaboos University. I-Manager's Journal of Educational Technology, 16(2), 50.

Atman Uslu, N., \& Usluel, Y. K. (2019). Predicting technology integration based on a conceptual framework for ICT use in education. Technology, Pedagogy and Education, 28(5), 517-531. https://doi. org/10.1080/1475939X.2019.1668293

Aydin, M. K., Gürol, M., \& Vanderlinde, R. (2016). Evaluating ict integration in turkish k-12 schools through teachers' views. Eurasia Journal of Mathematics, Science and Technology Education, 12(4), 747-766. doi: https://doi.org/10.12973/eurasia.2016.1227a

Badia Gargante, A., Meneses Naranjo, J., \& García Tamarit, C. (2015). Technology use for teaching and learning. Píxel-Bit. Revista de Medios y Educación, 46, 9-24. https://doi.org/10.12795/pixelbit. 2015.i46.01

Badia Garganté, A., Meneses Naranjo, J., \& García Tamarit, C. (2015). Technology use for teaching and learning. Píxel-Bit. Revista de Medios y Educación, (46), 9-24. doi: DOI: http://dx.doi. org/10.12795/pixelbit.2015.i46.01 
Badia, A., Meneses, J., \& Garcia, C. (2015). Technology use for teaching and learning. Píxel-Bit. Revista de Medios y Educación, 46, 9-24. doi: doi: 10.12795/pixelbit.2015.i46.01

Bergström, P., \& Mårell-Olsson, E. (2018). Power and control in the one-to-one computing classroom: students' perspectives on teachers' didactical design. Seminar.Net: Media, Technology and Lifelong Learning, 14(2), 160-173. Retrieved from http://umu.diva-portal.org/smash/get/diva2:1266186/ FULLTEXT01.pdf

Bermel, J. A. (2016). Using one-to-one computing for differentiated instruction in Iowa: An investigation of the impact of teachers' perceptions of teaching and learning (University of Northern Iowa). Retrieved from https://scholarworks.uni.edu/cgi/viewcontent.cgi?article=1341\&context=etd

Blau, I., Peled, Y., \& Nusan, A. (2016). Technological, pedagogical and content knowledge in one-toone classroom: Teachers developing “digital wisdom.”. Interactive Learning Environments, 24(6), 1215-1230. https://doi.org/10.1080/10494820.2014.978792

Bocchino III, H. S. (2017). High School Science Teachers' Perceptions of the Effects of One-To-One Computing Devices on Student Engagement (University of South Carolina). Retrieved from https:// scholarcommons.sc.edu/cgi/viewcontent.cgi?article $=5256 \&$ context $=$ etd

Buabeng-Andoh, C. (2012). An exploration of teachers' skills, perceptions and practices of ICT in teaching and learning in the Ghanaian second-cycle schools. Contemporary Educational Technology, 3(1), 36-49. doi: https://doi.org/10.30935/cedtech/6066

Collis, B., \& Moonen, J. (2002). Flexible learning in a digital world. Open Learning: The Journal of Open, Distance and e-Learning, 17(3), 217-230. https://doi.org/10.1080/0268051022000048228

Cviko, A., McKenney, S., \& Voogt, J. (2011). Teachers as (re-)designers of an ICT-rich learning environment for early literacy. The Annual ECER Meeting September 13-16, 2011. Retrieved from https:// ris.utwente.nl/ws/files/62529100/ECER_2011_Final.pdf

Dong, Y., Xu, C., Chai, C. S., \& Zhai, X. (2019). Exploring the structural relationship among teachers' technostress, technological pedagogical content knowledge (TPACK), computer self-efficacy and school support. The Asia-Pacific Education Researcher, 1-11. doi: https://doi.org/10.1007/ s40299-019-00461-5

Doron, E., \& Spektor-Levy, O. (2019). Transformations in teachers' views in one-to-one classes-Longitudinal case studies. Technology, Knowledge and Learning, 24(3), 437-460. https://doi.org/10.1007/ s10758-017-9349-5

Agyei, D.D., \& Voogt, J.. (2012). Developing technological pedagogical content knowledge in preservice mathematics teachers, through teacher design teams. Australasian Journal of Educational Technology, 28(4), 547-564. doi: doi: https://doi.org/10.14742/ajet.827

Fiorillo, M. (2015). Teacher perception of student engagement in a one-to-one computing environment (Saint Peter's University). Retrieved from http://librarydb.saintpeters.edu:8080/handle/123456789/ 202

Frank, K. A., Zhao, Y., \& Borman, K. (2004). Social capital and the diffusion of innovations within organizations: The case of Computer Technology in Schools. Sociology of Education, 77(2), 148171. https://doi.org/10.1177/003804070407700203

Frankson, E. M. (2018). Comparing Perceptions of Technology Between Teachers at 1: 1 Technology Schools and Teachers at Non-1: 1 Technology Schools (Carthage College). Retrieved from https://dspace.carthage.edu/bitstream/handle/123456789/8103/Frankson Masters Thesis FINAL. pdf? sequence $=1 \&$ is Allowed $=\mathrm{y}$.

Garthwait, A., \& Weller, H. G. (2005). A year in the life. Journal of Research on Technology in Education, 37(4), 361-377. https://doi.org/10.1080/15391523.2005.10782443

Gerez, J. G. (2019). Middle School Teachers' Perceptions Of The Integration Of Technology Into Pedagogy (University of New England). Retrieved from https://dune.une.edu/cgi/viewcontent.cgi?artic $1 \mathrm{e}=1228 \&$ context $=$ theses.

Håkansson Lindqvist, M. (2019). School leaders' practices for innovative use of digital technologies in schools. British Journal of Educational Technology, 50(3), 1226-1240. https://doi.org/10.1111/bjet. 12782

Harvey, G., \& Hurworth, R. (2006). Exploring program sustainability: Identifying factors in two educational initiatives in Victoria. Evaluation Journal of Australasia, 6(1), 36-44. https://doi.org/10. 1177/1035719X0600600106

Hershkovitz, A., \& Bransi, H. (2019). Comparación de las percepciones de los maestros en el entorno del aula de clase entre lecciones tradicionales y computarizadas "uno a uno" Comparing Teachers' Perceptions of Classroom Environment in Traditional and One-to-One Computing Lessons. Revista de Educación, 384, 147-173. https://doi.org/10.4438/1988-592X-RE-2019-384-406 
Hershkovitz, A., \& Karni, O. (2018). Borders of change: A holistic exploration of teaching in one-to-one computing programs. Computers \& Education, 125, 429-443. https://doi.org/10.1016/j.compedu. 2018.06.026

Higgins, K. (2015). The student-teacher relationship in a one-to-one technology classroom: a case study (Rowan University). Retrieved from https://rdw.rowan.edu/etd/436

Hilton, J. T. (2016). A case study of the application of SAMR and TPACK for reflection on technology integration into two social studies classrooms. The Social Studies, 107(2), 68-73. https://doi.org/10. 1080/00377996.2015.1124376

Jacob, J. K. (2020). Teachers' Perceptions of a One-to-One Teacher Laptop Program and Teacher Technology Efficacy (Walden University). Retrieved from https://scholarworks.waldenu.edu/cgi/viewc ontent.cgi? article $=9485 \&$ context $=$ dissertations

Jeffery, L. (2019). Preservice Teachers' Perceptions of Readiness for Teaching in a 1: 1 Classroom (University of New Mexico - Main Campus). Retrieved from https://digitalrepository.unm.edu/cgi/viewc ontent.cgi?article $=1288 \&$ context=educ_teelp_etds

Kafyulilo, A., Fisser, P., \& Voogt, J. (2016). Factors affecting teachers' continuation of technology use in teaching. Education and Information Technologies, 21(6), 1535-1554. https://doi.org/10.1007/ s10639-015-9398-0

Kamel Boulos, M. N., \& Wheeler, S. (2007). The emerging web 2.0 social software: An enabling suite of sociable technologies in health and health care education1. Health Information \& Libraries Journal, 24(1), 2-23. https://doi.org/10.1111/j.1471-1842.2007.00701.x

Kim, H. J., Choi, J., \& Lee, S. (2019). Teacher experience of integrating tablets in one-to-one environments: Implications for orchestrating learning. Education Sciences, 9(2), 87. https://doi.org/10. 3390/educsci9020087

Kirkland, A. B. (2014). Models for technology integration in the learning commons. School Libraries in Canada, 32(1), 14-18.

Knops, M. (2017). Teachers' perceptions of professional development for one-to-one technology integration in an elementary school setting (Northern Illinois University). Retrieved from https://commons. lib.niu.edu/handle/10843/21477

Laurillard, D. (2013). Teaching as a design science: Building pedagogical patterns for learning and technology. doi: https://doi.org/10.4324/9780203125083

Lawrence, E. K. (2018). Exploring high school teachers' perceptions of facilitating conditions prior to the implementation of a 1: 1 learning environment (Northern Illinois University). Retrieved from https://commons.lib.niu.edu/bitstream/handle/10843/21488/Lawrence_niu_0162D_13268.pdf? sequence $=1$

Lee, J., Spires, H., Wiebe, E., Hollebrands, K., \& Young, C. (2015). Portraits of one-to-one learning environments in a new learning ecology. International Journal of Learning, Teaching and Educational Research, 10(3).

Lei, J. (2010). Conditions for ubiquitous computing: What can be learned from a longitudinal study. Computers in the Schools, 27(1), 35-53. https://doi.org/10.1080/07380560903536264

Lei, J., Conway, P. F., \& Zhao, Y. (2007). The digital pencil: One-to-one computing for children. Routledge.

Li, S. C. (2010). Social capital, empowerment and educational change: A scenario of permeation of oneto-one technology in school. Journal of Computer Assisted Learning, 26(4), 284-295. https://doi. org/10.1111/j.1365-2729.2010.00350.x

Maiima, F., Ondigi, S., \& Mavsi, R. (2013). Teachers' perception about integration of ICT in teaching and learning. International Journal of Arts and Commerce, 2(3), 27-32.

Martin, L. A. (2015). How Teachers' Perceptions of Their Writing Instruction Have Changed Over Time With the Introduction of a One-To-One Learning Environment? (Hamline University). Retrieved from https://digitalcommons.hamline.edu/hse_all/103/

Michalsky, T., Zion, M., \& Mevarech, Z. R. (2007). Developing students' metacognitive awareness in asynchronous learning networks in comparison to face-to-face discussion groups. Journal of Educational Computing Research, 36(4), 395-424. https://doi.org/10.2190/320V-8H4W-1123-44R6

Mor, Y., Ferguson, R., \& Wasson, B. (2015). Editorial: Learning design, teacher inquiry into student learning and learning analytics: A call for action. British Journal of Educational Technology, 46(2), 221-229. https://doi.org/10.1111/bjet.12273

Munyengabe, S., Yiyi, Z., Haiyan, H., \& Hitimana, S. (2017). Primary teachers' perceptions on ICT integration for enhancing teaching and learning through the implementation of One Laptop per Child 
Program in primary schools of Rwanda. Eurasia Journal of Mathematics, Science and Technology Education, 13(11), 7193-7204. doi: https://doi.org/10.12973/ejmste/79044

Peled, Y., Kali, Y., \& Dori, Y. J. (2011). School principals' influence on science teachers' technology implementation: A retrospective analysis. International Journal of Leadership in Education, 14(2). https://doi.org/10.1080/13603124.2010.524249

Peled, Yehuda, Blau, I., \& Grinberg, R. (2015). Does one-to-one computing in a junior-high-school change the pedagogical perspectives of teachers and their educational discourse? Interdisciplinary Journal of E-Skills and Lifelong Learning, 11, 257-271. doi: doi: https://doi.org/10.28945/2311

Perry, N. D. (2018). Teacher attitudes and Beliefs about Successfully Integrating Technology in their Classroom During a one-to-one Technology Initiative and the Factors that Lead to Adaptations in their Instructional Practice and Possible Influence on Standardized Test Achievement (Youngstown State University). Retrieved from http://rave.ohiolink.edu/etdc/view?acc_num=ysu152223367629 2274

Redmond, A. (2018). Middle School Teachers' Perceptions of Self-Efficacy, Preparedness, and Pedagogical Transformation to Implement One-To-One Instructional Technology: Implications for Educational Leaders (Atlanta University). Retrieved from https://pdfs.semanticscholar.org/1da4/dfab8 f94b1646e615cd1827a8f0fea813076.pdf

Sahoo, R. K. (2019). Exploring the Changes in Teaching Strategies Enabled by Information and Communication Technology. International Journal of Emerging Issues in Early Childhood Education, 1(2), 66-80. doi: https://doi.org/10.31098/ijtaese.v1i2.34

Salam, S., Zeng, J., Pathan, Z. H., Latif, Z., \& Shaheen, A. (2018). Impediments to the integration of ICT in public schools of contemporary societies: A review of literature. Journal of Information Processing Systems, 14(1), 252-269. https://doi.org/10.3745/JIPS.04.0062

Scott, P., \& Mouza, C. (2007). The impact of professional development on teacher learning, practice and leadership skills: A study on the integration of Technology in the Teaching of writing. Journal of Educational Computing Research, 37(3), 229-266. https://doi.org/10.2190/EC.37.3.b

Selwyn, N., Nemorin, S., Bulfin, S., \& Johnson, N. F. (2017). Left to their own devices: The everyday realities of one-to-one classrooms. Oxford Review of Education, 43(3), 289-310. https://doi.org/10. 1080/03054985.2017.1305047

Shapley, K. S., Sheehan, D., Maloney, C., \& Caranikas-Walker, F. (2010). Evaluating the implementation fidelity of technology immersion and its relationship with student achievement. The Journal of Technology, Learning and Assessment, 9(4).

Sockman, B. R. (2007). TEACHERS'PERCEPTIONS OF THEIR TEACHING STYLE DEVELOPMENT IN ONE-TO-ONE LEARNING ENVIRONMENTS (Penn state). Retrieved from https://etda.libraries. psu.edu/catalog/7769

Sprenger, K. R. (2010). Perceptions of change in teaching styles during a one-to-one laptop initiative (Pennstate). Retrieved from https://etda.libraries.psu.edu/catalog/11353

Strudler, N., \& Schrader, P. G. (2016). Engage, empower, explore: An evaluation study of one-to-one implementation at twelve urban middle schools. SITE 2016 Conference. Savannah, GA.

Tondeur, J., van Keer, H., van Braak, J., \& Valcke, M. (2008). ICT integration in the classroom: Challenging the potential of a school policy. Computers \& Education, 51(1), 212-223. https://doi.org/10. 1016/j.compedu.2007.05.003

Varier, D., Dumke, E. K., Abrams, L. M., Conklin, S. B., Barnes, J. S., \& Hoover, N. R. (2017). Potential of one-to-one technologies in the classroom: Teachers and students weigh in. Educational Technology Research and Development, 65(4), 967-992. https://doi.org/10.1007/s11423-017-9509-2

Vu, P., Fredrickson, S., \& Gaskill, M. (2019). One-to-one initiative implementation from insiders' perspectives. TechTrends, 63(1), 62-67. https://doi.org/10.1007/s11528-018-0359-5

Wang, S., \& Zhang, D. (2019). Student-centred teaching, deep learning and self-reported ability improvement in higher education: Evidence from mainland China. Innovations in Education and Teaching International, 56(5), 581-593. https://doi.org/10.1080/14703297.2018.1490662

Williams, N. L., \& Larwin, K. H. (2016). One-to-one computing and student achievement in Ohio high schools. Journal of Research on Technology in Education, 48(3), 143-158. https://doi.org/10.1080/ 15391523.2016.1175857

Willis, R. L., Lynch, D., Fradale, P., \& Yeigh, T. (2019). Influences on purposeful implementation of ICT into the classroom: An exploratory study of K-12 teachers. Education and Information Technologies, 24(1), 63-77. https://doi.org/10.1007/s10639-018-9760-0

Wolfe, A. M. (2018). English/language arts teachers' and principals' perceptions of the value of oneto-one student laptops, in year 5 of the initiative, in 3 urban high schools (The university of Texas 
at Austin). Retrieved from https://repositories.lib.utexas.edu/bitstream/handle/2152/75731/WOLFETREATISE-2018.pdf?sequence $=1$

Wright, S. (2019). Secondary Teachers' Perceptions Regarding the Professional Development Practices Provided for the Implementation of a 1: 1 Device Initiative. Retrieved from https://eric.ed.gov/?id= ED597714

Yuen, A., Law, N., \& Wong, K. (2003). ICT implementation and school leadership: Case studies of ICT integration in teaching and learning. Journal of Educational Administration, 41(2), 158-170. https:// doi.org/10.1108/09578230310464666

Publisher's note Springer Nature remains neutral with regard to jurisdictional claims in published maps and institutional affiliations.

\section{Authors and Affiliations}

\section{Yehuda Peled ${ }^{1}$ (D) $\cdot$ Ina Blau $^{2}$ (D) $\cdot$ Ronen Grinberg $^{3}$}

Ina Blau

inabl@openu.ac.il

1 Department of Education, Western Galilee College, Derech HaMichlala, P.O.B. 2125, Acco, Israel

2 Department of Education and Psychology, The Open University of Israel, 1 University Road, P.O.B. 808, 43107 Ra'anana, Israel

3 Eilon, Israel 